\title{
Stand Structure and Geographic Conditions of Natural Selection Forests in Central Hokkaido, Northern Japan
}

\author{
Toshiaki Owari*, Masaki Matsui*, Hiroshi Inukai* and Mikio Kaji*
}

\begin{abstract}
Selection forest is a forest managed with the uneven-aged silvicultural system, in which trees are removed individually from a large area periodically. Selection system has been used to manage natural forests in Hokkaido, northern Japan. This study demonstrated the characteristics of natural selection forests in central Hokkaido. A case analysis was conducted at the University of Tokyo (UT) Hokkaido Forest to closely examine the structure and geography of selection stands. We used a total of 1,382 sample plots that had established in selection stands during 1996-2005 and the spatial information on stand classification with 10-m grid digital elevation model. We calculated the mean dominance and density of trees with $\mathrm{DBH} \geq 5 \mathrm{~cm}$, which were $30.7 \mathrm{~m}^{2} \mathrm{ha}^{-1}$ and 792 individuals $\mathrm{ha}^{-1}$, respectively. Juveniles (Height $\geq 1.3 \mathrm{~m}$ and $\mathrm{DBH}<5 \mathrm{~cm}$ ) had a mean density of 561 individuals $\mathrm{ha}^{-1}$. An asymmetric and peaked distribution was observed in tree and juvenile density. The predominant tree species included Sakhalin fir (Abies sachalinensis), Yezo spruce (Picea jezoensis), Japanese linden (Tilia japonica), and painted maple (Acer mono). An inverse J-shaped diameter distribution was maintained in tree density. Selection stands were mostly located on an area between $300-600 \mathrm{~m}$ a.s.1..
\end{abstract}

Keywords: geographic condition, selection forest, stand structure, Hokkaido

\section{INTRODUCTION}

Selection forest is a forest treated and managed under the uneven-aged silvicultural system called 'selection system', in which trees are selected to be removed individually or in small groups from a large area periodically (ZINGG, 1999; ZINGG et al., 1999). In a selection forest, trees with all diameter (or age) classes are closely intermixed over a small area (SснüTZ, 2006). The whole area is continuously covered, the growing stock changes only on small areas, and consecutive regeneration and harvesting are possible (ZINGG et al., 1999). A relatively steady state of structure and functions can be realized over time as compared with even-aged forest management (O'HARA et al., 2007).

Selection forests are present in central Europe including

Corresponding author: Toshiaki Owari

E-mail: owari@uf.a.u-tokyo.ac.jp

*Hokkaido Forest, Graduate School of Agricultural and Life Sciences, The University of Tokyo, 2 jo Kita

1, Yamabe, Furano, Hokkaido 079-1561, Japan
Austria, France, Germany, Slovenia, and Switzerland, where the main species are European silver fir (Abies alba MrL.), Norway spruce (Picea abies (L.) H. KARST.), and European beech (Fagus sylvatica L.) (ScHüTZ, 2001). The management of northern hardwood forests uses selection system in North America (NYLAND, 1998), where sugar maple (Acer saccharum MARSH.) and American beech (Fagus grandifolia EHRH.) are key tree species. Selection forests can be found in various parts of Japan (OHGANe, 1981). In Hokkaido, northernmost Japan, natural forest covers an area of 3.7 million ha. It is mainly comprised of multi-aged and mixed stands, and selection system has been widely employed since the early $20^{\text {th }}$ century as a major option to manage natural forests (Yoshida et al., 2006). Although previous studies portrayed selection forests in Hokkaido (e.g., ISHIBASHI, 1999; YAMAMOTO et al., 1995; YoSHIDA et al., 2006), there are limited data on their structural and geographic features at the forest management scale.

The purpose of this study was to demonstrate the basic characteristics of selection forests in central Hokkaido. A case analysis was conducted at the University of Tokyo (UT) Hokkaido Forest to closely examine the structure (tree dominance and density, species composition, diameter distribution) and geography (elevation, inclination, slope aspect) of selection stands. Because of their greater complexity and heterogeneity 
than even-aged stands (O'HARA et al., 2007), we aimed to represent spatial variations in selection forests. Stand-level inventory data that had collected throughout the UT Hokkaido Forest was used for the analysis. We concluded by briefly characterizing selection forests in central Hokkaido in comparison with central Europe.

\section{MATERIALS AND METHODS}

The UT Hokkaido Forest is located in Furano, central Hokkaido $\left(43^{\circ} 10-20^{\prime} \mathrm{N}, 142^{\circ} 18-40^{\prime} \mathrm{E}, 190-1,460 \mathrm{~m}\right.$ a.s.l.), with an area of 22,733 ha. According to observations at the Arboretum $\left(43^{\circ} 13^{\prime} \mathrm{N}, 142^{\circ} 23^{\prime} \mathrm{E}, 230 \mathrm{~m}\right.$ a.s.l.), mean annual temperature and precipitation during $1996-2005$ were $6.3{ }^{\circ} \mathrm{C}$ and $1,254 \mathrm{~mm}$, respectively (The ToKyo UnIVERsity Forest in HoKkaIDo, 2007). Snow (approximately $1 \mathrm{~m}$ in depth) covers the ground from November to April. The typical substrate and soil type are welded tuff (GEOLOGICAL SURVEY OF JAPAN, 2003) and dark and brown forest soil (ASAHI, 1963). It is situated in an area of mixed forest with coniferous and broad-leaved species between the cool-temperate and the sub-boreal zone, and is mostly covered by natural forests. The forest floor is often occupied by dwarf bamboo Sasa senanensis (Franch. \& SAVAT.) ReHD. or Sasa kurilensis (RUPR.) MAKINO \& SHIBATA.

Long-term and large-scale experiments of the stand-based forest management system (SFMS) have been conducted at the UT Hokkaido Forest since 1958. The idea behind the SFMS is that management should be adaptive to the conditions of each stand for maximizing multiple public and economic functions of forest ecosystems (TAKAHASHI, 2001). A natural forest can be classified into several stand types according to the difficulty of natural regeneration, site conditions, and timber quality. A stand in which natural regeneration is expectable so that selection cutting is applicable can be classified as selection stand.

This study investigated all selection stands that had been classified and managed during the $11^{\text {th }}$ management planning period (1996-2005). Stand classification was conducted based on careful on-site observations with intensive ground surveying. The cutting cycle was either 10 or 20 years, depending upon site conditions and the growth rate of stands. The rate of removals was normally $16-17 \%$ of the growing stock, which was less than the growth rate (THE ToKYo UNIVERSiTy FOREST IN HOKKAIDO, 1997).

We used a total of 1,382 sample plots that had established in selection stands one year before harvesting (1995-2004) (Fig. 1). The plot size was typically 0.25 ha $(50 \mathrm{~m} \times 50 \mathrm{~m})$, and the species and diameter at breast height (DBH) for all living trees with $\mathrm{DBH} \geq 5 \mathrm{~cm}$ were recorded in each plot. The number of juveniles ( $\geq 1.3 \mathrm{~m}$ in height and $<5 \mathrm{~cm}$ in DBH) by tree species were also recorded. Single-tree selection cutting had been conducted on the selection stands at least $1-3$ times before the measurements.

Tree dominance (represented by the sum of basal areas), tree density, and juvenile density were examined by calculat-

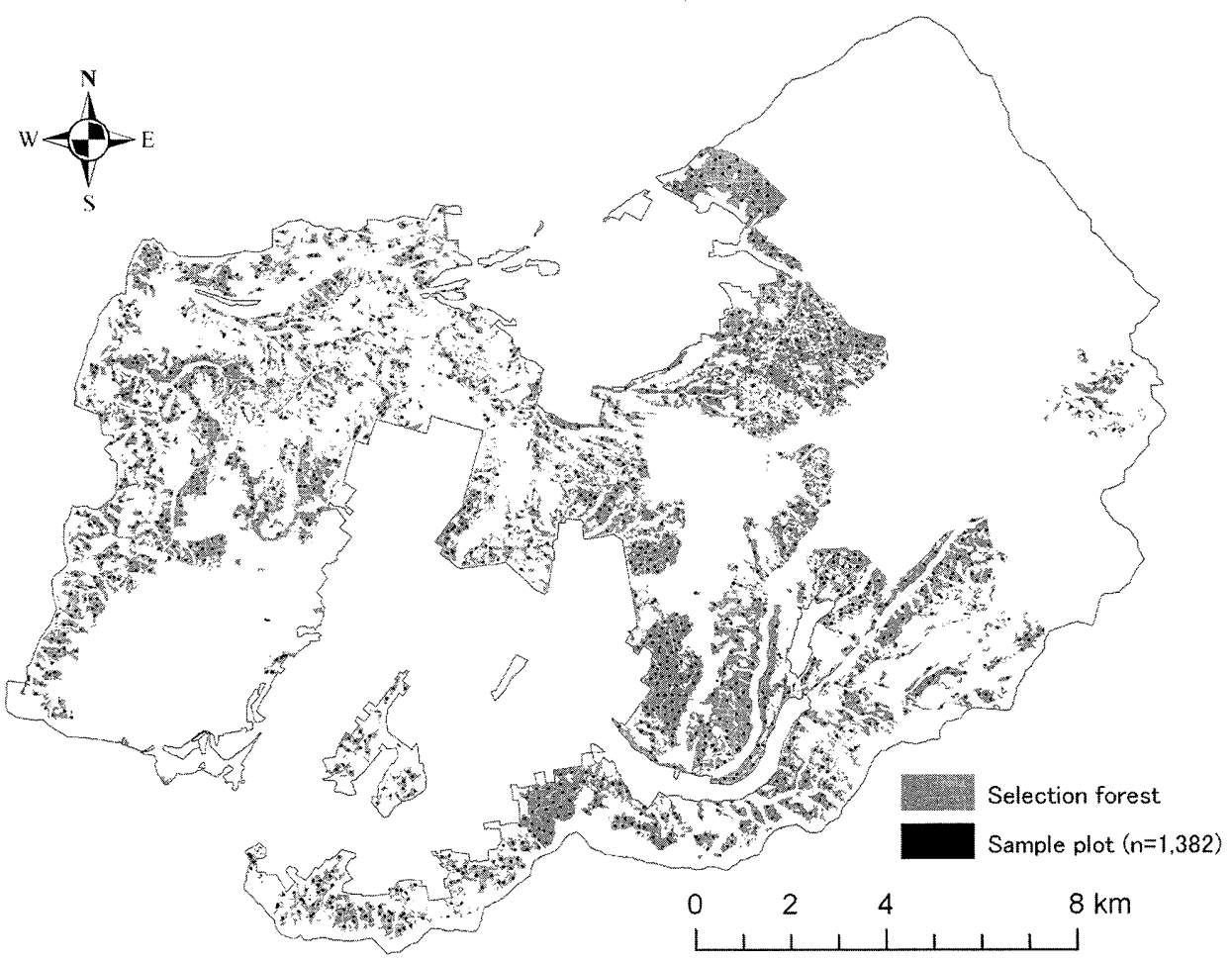

Fig. 1 Location of selection forests and sample plots 
ing the frequency distribution of sample plots. The basic statistics (mean, standard deviation, minimum, maximum, and median) with skewness and kurtosis were also computed. Skewness characterizes the degree of asymmetry of a distribution around its mean, and kurtosis measures the relative peakiness or flatness of a distribution compared with the normal distribution (Brown, 1997). The skewness-kurtosis test examined the normality hypothesis. Species composition was analyzed by listing observed tree species with their dominance, density and constancy (percentage occurrence in sample plots). Diameter distribution was investigated by calculating tree dominance, density and consistency according to the DBH classes (2 $\mathrm{cm}$ intervals).

The analysis of geographic conditions used the spatial information on selection forests, which was developed by converting the management planning (stand classification) maps into polygon features of the geographic information system (GIS) (OWARI et al., 2009). Elevation, inclination, and slope aspect were examined through spatial analyses using GIS software ArcGIS 9.3 (ESRI Corp., CA, USA) with 10-m grid digital elevation models of GISMAP Terrain Ver. 2.00 (Hokkaido Chizu Co. Ltd., Asahikawa, Japan).

\section{RESULTS}

Tree Dominance and Density

The frequency distribution of 1,382 sample plots by tree dominance was shown in Fig. 2. We observed a mono-modal distribution, having a mean basal area of $30.7 \mathrm{~m}^{2} \mathrm{ha}^{-1}$. Skewness was close to zero so that the distribution was quite symmetric. Positive kurtosis indicated a relatively peaked distribu-

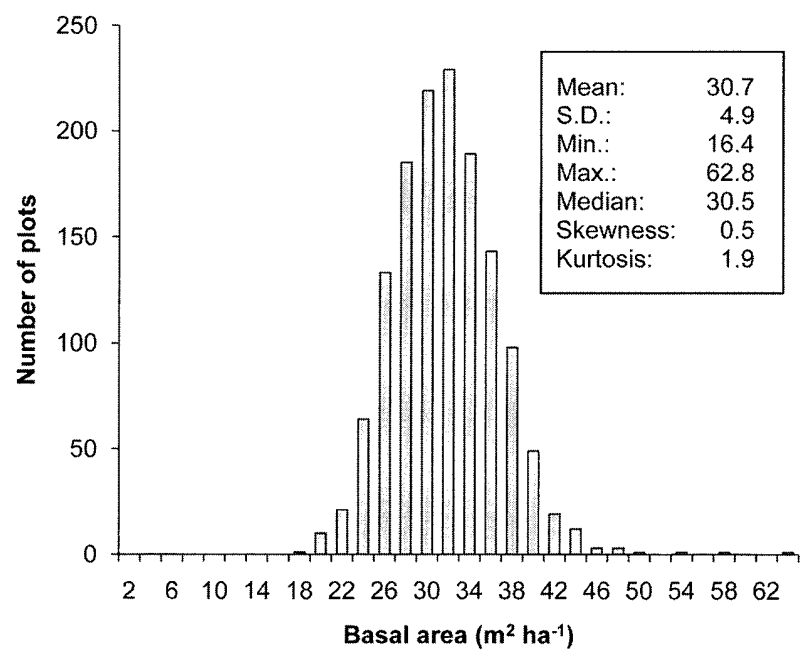

Fig. 2 Frequency of observed sample plots according to the tree dominance

Living individuals with $\mathrm{DBH} \geq 5 \mathrm{~cm}$ were investigated. tion. The skewness-kurtosis test rejected the normality hypothesis $(p<0.001)$. Plots with a basal area of $>50$ or $<20$ $\mathrm{m}^{2} \mathrm{ha}^{-1}$ were rare. The mean growing stock was $281.4 \mathrm{~m}^{3} \mathrm{ha}^{-1}$.

The mean density of trees with DBH $\geq 5 \mathrm{~cm}$ was 792 individuals ha $^{-1}$ (Fig. 3). Even though a mono-modal frequency distribution was depicted, positive skewness and kurtosis indicated a relatively asymmetric and peaked distribution. The normality hypothesis was rejected $(p<0.001)$.

The plot frequency according to the juvenile density had a

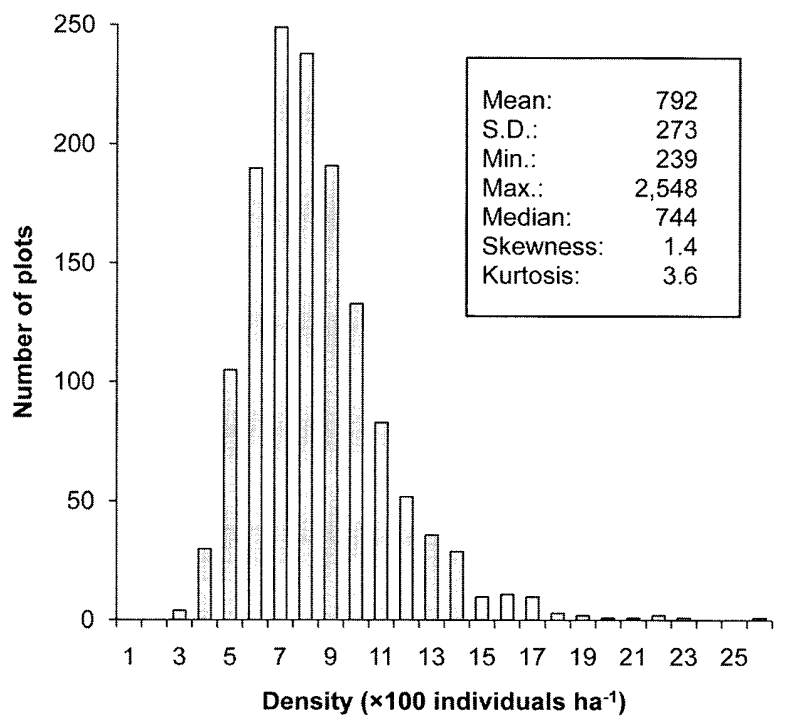

Fig. 3 Frequency of observed sample plots according to the tree density

Living individuals with $\mathrm{DBH} \geq 5 \mathrm{~cm}$ were investigated.

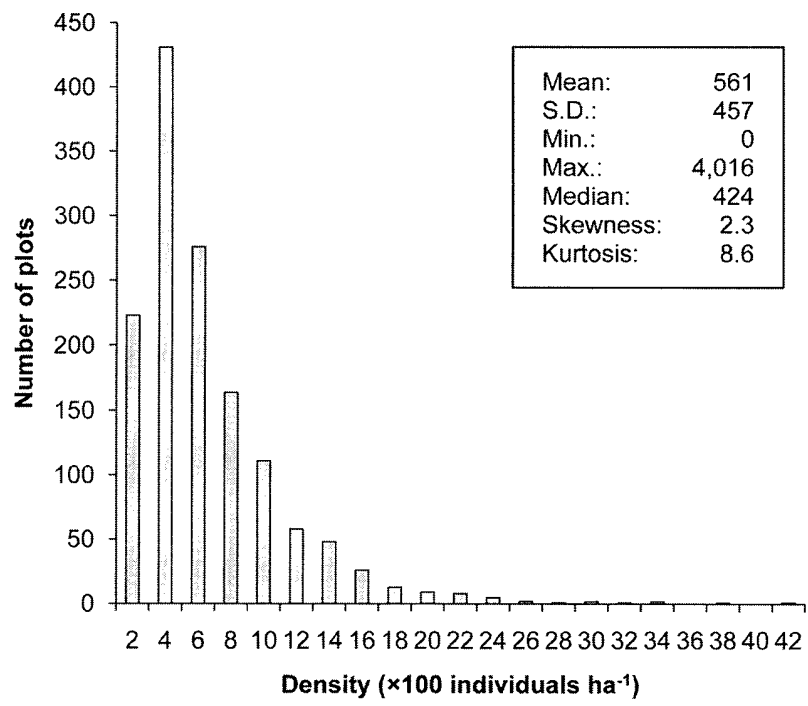

Fig. 4 Frequency of observed sample plots according to the juvenile density

Living individuals with DBH $<5 \mathrm{~cm}$ and Height $\geq 1.3 \mathrm{~m}$ were investigated. 
mono-modal and skewed distribution (Fig. 4). Highly positive skewness and kurtosis indicated that the majority of the densities were concentrated on the low value end. The mean juvenile density of 561 individuals ha ${ }^{-1}$ was relatively large compared to its median value (424 individuals $\mathrm{ha}^{-1}$ ). The null hypothesis of normality was rejected $(p<0.001)$.

\section{Species Composition}

Conifers and broad-leaved trees had a mean basal area of 17.5 and $13.2 \mathrm{~m}^{2} \mathrm{ha}^{-1}$, and a mean density of 373 and 419 individuals $\mathrm{ha}^{-1}$, respectively. Despite their superior dominance, a relatively small number of conifers were observed in selection stands. Broad-leaved trees took a relatively large share in juveniles, having 375 individuals $\mathrm{ha}^{-1}$. Conifers had 186 juveniles $\mathrm{ha}^{-1}$ on average.

A total of 45 tree species were recorded, and we listed common tree species observed in sample plots as Table 1. Abies sachalinensis (Fr. SCHM.) MASTERS had the highest tree domi- nance, followed by Picea jezoensis (SiEb. \& Zucc.) Carr. These two conifers gained 55\% of the tree dominance in selection stands. The tree and juvenile densities of $P$. jezoensis were relatively low despite its high dominance. $A$. sachalinensis trees and juveniles occurred at nearly all sample plots, while we did not observe $P$. jezoensis juveniles at $30 \%$ of the plots. Other coniferous species included Picea glehnii Masters and Taxus cuspidata SIEBOLD \& ZuCC..

Among broad-leaved tree species, Tilia japonica (MiQ.) Simonkai (recorded as Tilia spp.) and Acer mono Maxim. achieved relatively high dominances and densities. These tree species were observed in most of the sample plots. Other broad-leaved tree species with relatively high dominance included Kalopanax pictus (Thunb.) NAKAI, Quercus crispula Blume, and Ulmus laciniata (TrauTV.) MaYR (recorded as Ulmus spp.). In these species, juveniles had a relatively low density and occurred only at $34-41 \%$ of the plots.

Table 1 Tree species observed in selection stands

\begin{tabular}{|c|c|c|c|c|c|}
\hline \multirow[b]{2}{*}{ Species } & \multicolumn{3}{|c|}{ Trees } & \multicolumn{2}{|c|}{ Juveniles } \\
\hline & $\begin{array}{l}\text { Mean dominance } \\
\mathrm{m}^{2} \mathrm{ha}^{-1}\end{array}$ & $\begin{array}{l}\text { Mean density } \\
\text { individuals } \mathrm{ha}^{-1}\end{array}$ & $\begin{array}{c}\text { Constancy } \\
\% \\
\end{array}$ & $\begin{array}{l}\text { Mean density } \\
\text { individuals } \text { ha }^{-1}\end{array}$ & $\begin{array}{c}\text { Constancy } \\
\% \\
\end{array}$ \\
\hline Abies sachalinensis & 12.8 & 298 & 100 & 162 & 99 \\
\hline Picea jezoensis & 4.1 & 56 & 85 & 17 & 70 \\
\hline Tilia spp. & 3.2 & 95 & 97 & 77 & 95 \\
\hline Acer mono & 2.3 & 62 & 98 & 54 & 90 \\
\hline Kalopanax pictus & 1.0 & 16 & 86 & 7 & 41 \\
\hline Quercus crispula & 0.9 & 11 & 66 & 5 & 34 \\
\hline Ulmus spp. & 0.9 & 21 & 77 & 8 & 38 \\
\hline Other Acer spp. & 0.5 & 31 & 87 & 58 & 72 \\
\hline Magnolia obovata & 0.5 & 22 & 80 & 17 & 72 \\
\hline Betula maximowicziana & 0.5 & 8 & 57 & 2 & 17 \\
\hline Ostrya japonica & 0.5 & 8 & 38 & 3 & 16 \\
\hline Picea glehnii & 0.4 & 6 & 31 & 2 & 15 \\
\hline Prunus ssiori & 0.4 & 20 & 57 & 31 & 63 \\
\hline Sorbus commixta var. rufoferruginea & 0.3 & 27 & 78 & 22 & 67 \\
\hline Other Prunus spp. & 0.3 & 14 & 68 & 7 & 42 \\
\hline Aria alnifolia & 0.2 & 12 & 67 & 8 & 43 \\
\hline Betula ermanii & 0.2 & 5 & 21 & 4 & 13 \\
\hline Fraxinus mandshurica var. japonica & 0.2 & 4 & 27 & 2 & 12 \\
\hline Cercidiphyllum japonicum & 0.2 & 3 & 28 & 1 & 15 \\
\hline Acanthopanax sciadophylloides & 0.2 & 11 & 58 & 7 & 37 \\
\hline Magnolia kobus var. borealis & 0.2 & 9 & 57 & 17 & 55 \\
\hline Phellodendron amurense & 0.2 & 8 & 62 & 2 & 24 \\
\hline Taxus cuspidata & 0.1 & 10 & 56 & 4 & 29 \\
\hline
\end{tabular}

Common tree species ( $B A \geq 0.1 \mathrm{~m}^{2} \mathrm{ha}^{-1}$ ) were listed. Constancy is the percentage occurrence in 1,382 sample plots.

Tilia spp.: T. japonica and T. maximowicziana; Ulmus spp.: U. laciniata and U. davidiana var. japonica; Other Acer spp.: A. japonicum and A. palmatum var. amoenum; Other Prunus spp.: P. sargentii and P. maximowiczii. 


\section{Diameter Distribution}

The mean dominances of conifers and broad-leaved trees by DBH class ( $2 \mathrm{~cm}$ intervals) were shown in Fig. 5 . A monomodal distribution was observed in each species group, having a mode at 40 and $30 \mathrm{~cm}$ of $\mathrm{DBH}$, respectively. The dominance of conifers exceeded that of broad-leaved trees at DBH classes between $24-68 \mathrm{~cm}$, and vice versa at DBH $\leq 22 \mathrm{~cm}$ and $\geq 70 \mathrm{~cm}$.

As to the mean tree densities by DBH class, we observed an inverse J-shaped distribution curve in both conifers and broad-leaved trees (Fig. 6). A relatively large number of broadleaved trees were observed at DBH classes of less than $22 \mathrm{~cm}$. An inverse S-shaped curve was drawn for the constancy distribution (Fig. 7). Constancy decreased gradually as the DBH becomes large. Broad-leaved trees had a relatively large constancy in small DBH classes, while conifers occurred more in sample plots at DBH classes between $26-66 \mathrm{~cm}$.

\section{Geographic Conditions}

Selection stands had an area of 5,111 ha, accounting for 23\% of the UT Hokkaido Forest. The spatial distribution by elevation class was shown in Fig. 8. The mean elevation was $465 \mathrm{~m}$ a.s.l. with a range between $192-842 \mathrm{~m}$ a.s.l.. Of the selection forests, $91 \%$ were located on $300-600 \mathrm{~m}$ a.s.l..

The mean inclination of selection stands was 14.9 degree. $90 \%$ of the selection stands attributed less than 30 degree, in which the distribution was fairly even (Fig. 9). The slope as-

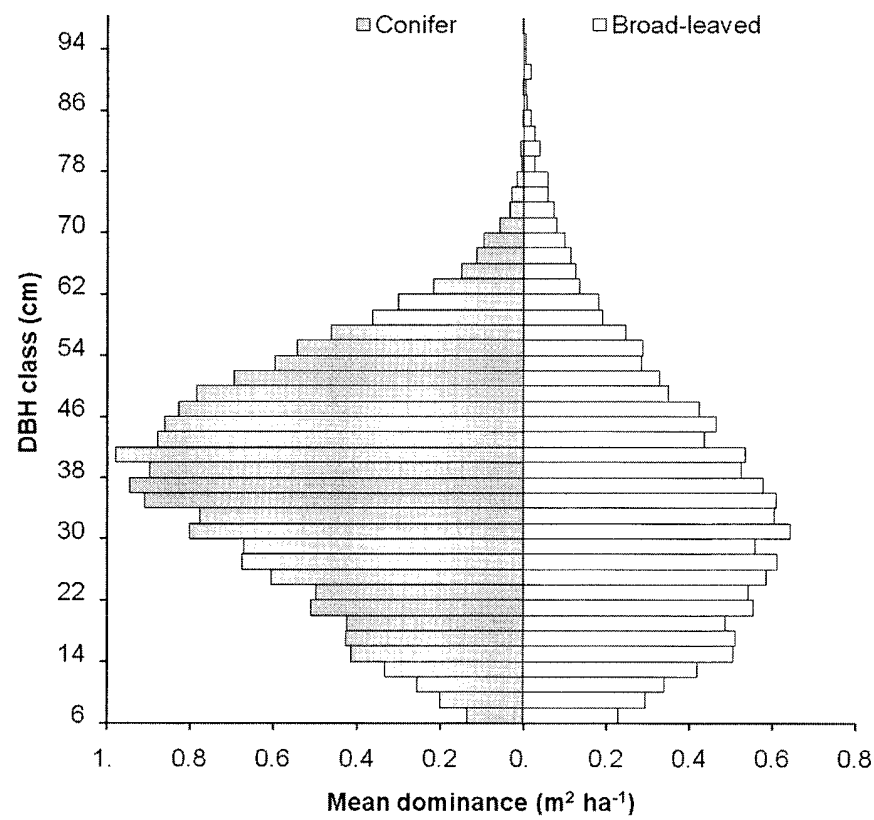

Fig. 5 Mean dominances of coniferous and broad-leaved trees by diameter class pect was somewhat biased to the west according to the general trend at the UT Hokkaido Forest (Fig. 10). 52\% of selection stands were located on a northwest-west-southwest facing slope.

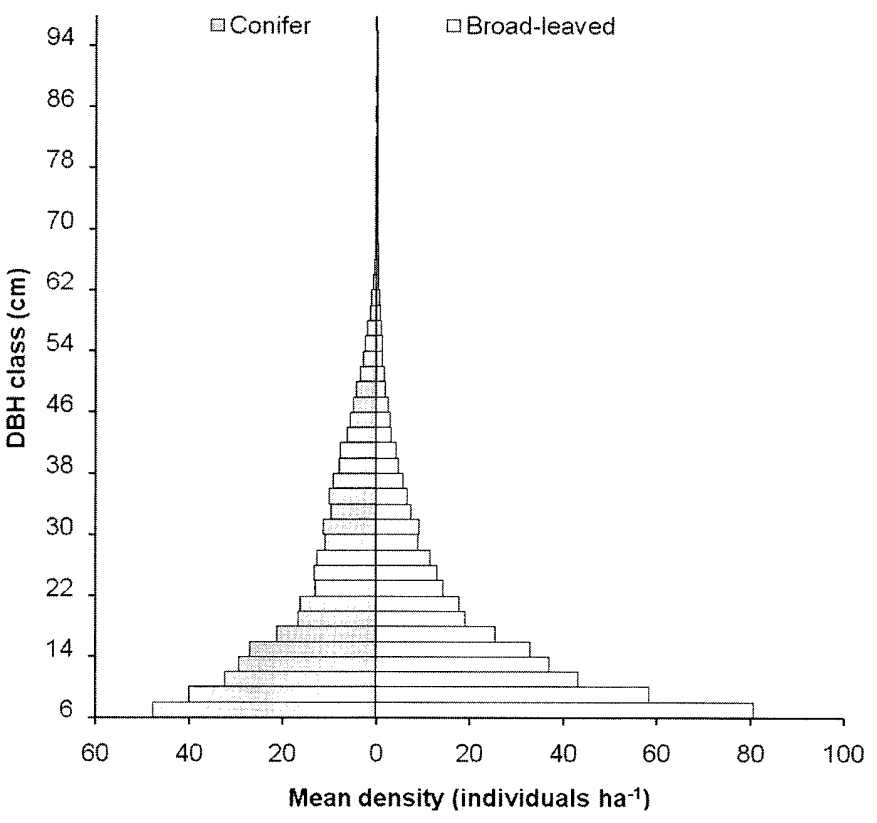

Fig. 6 Mean densities of coniferous and broad-leaved trees by diameter class

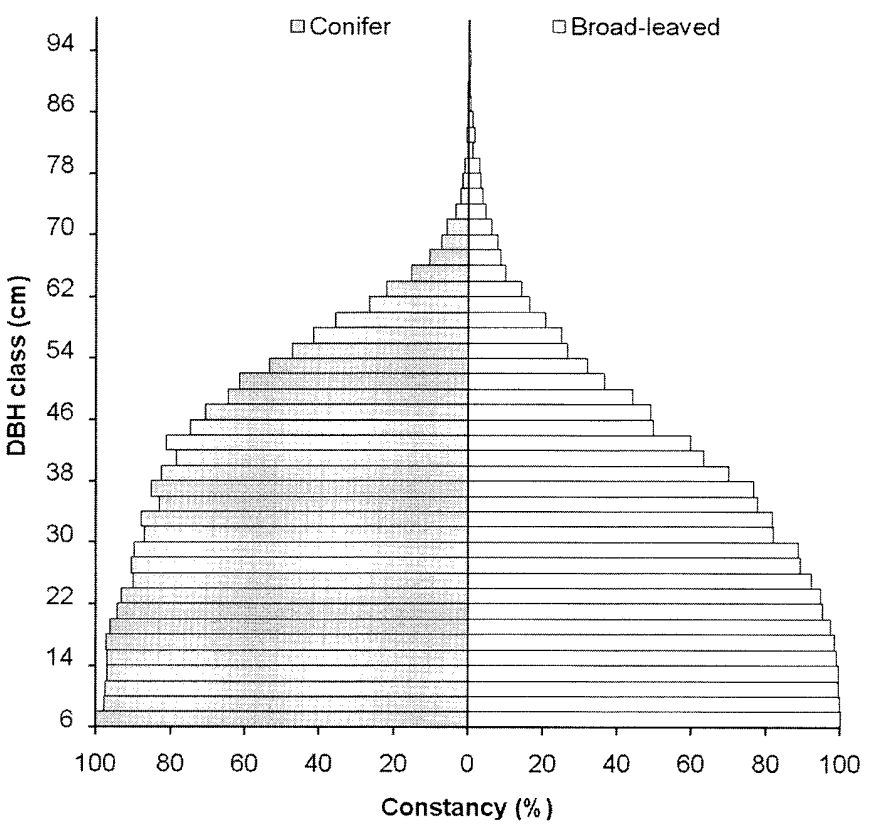

Fig. 7 Constancies of coniferous and broad-leaved trees by diameter class 


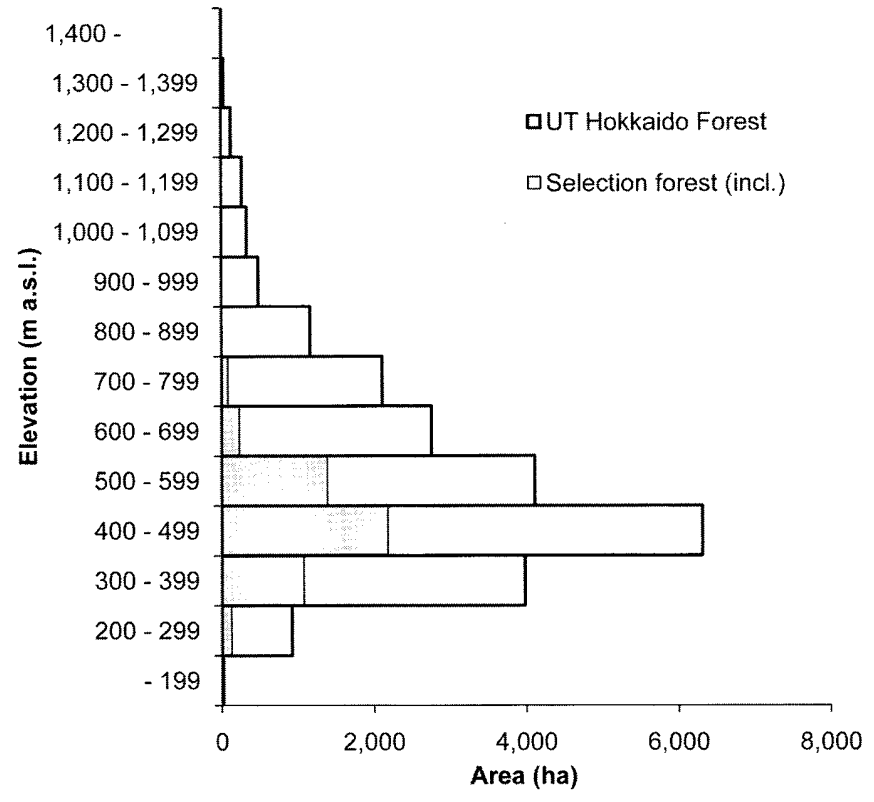

Fig. 8 Area of selection forests by elevation

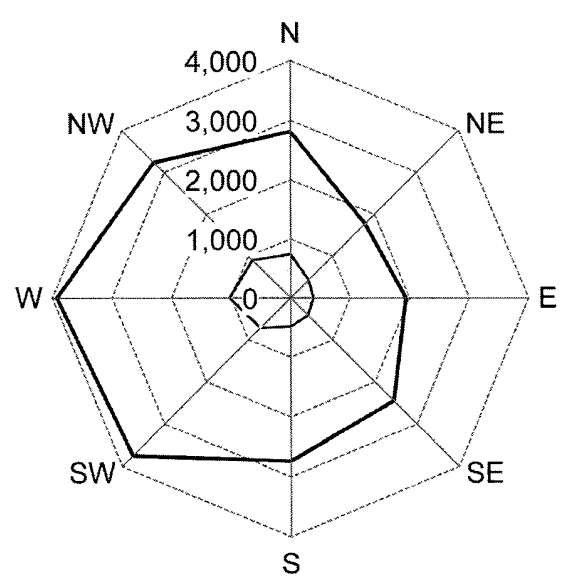

口UT Hokkaido Forest $\square$ Selection forest (incl.)

Fig. 10 Area of selection forests by slope aspect

\section{DISCUSSION}

Results in this study are consistent with previous research reporting tree dominance and density of selection forests in Hokkaido (ISHIBASHI, 1999; YoSHIDA et al., 2006). We observed a relatively low dominance with high density compared to selection (or plenter) forests in Switzerland (O'HARA et al., 2007), where conifers with large diameter are rather dominant. Although the initial idea of selection system in Hokkaido was heavily influenced by European experiences (OHGANE, 1981), the structural differences of selection forests between two regions are evident. ҮАмАмото et al. (1996) analyzed the struc-

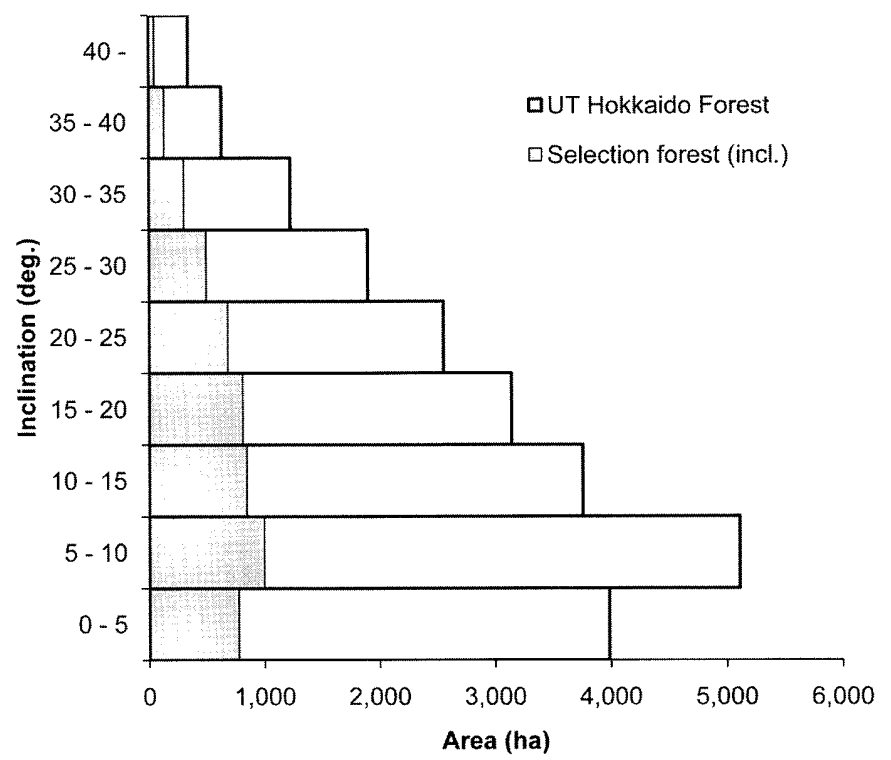

Fig. 9 Area of selection forests by inclination

ture of selection stands at the UT Hokkaido Forest during 1986-1995, using 1,179 sample plots established under the $10^{\text {th }}$ forest management plan. The mean tree dominance and density were $28.0 \mathrm{~m}^{2} \mathrm{ha}^{-1}$ and 754 individuals ha ${ }^{-1}$, respectively, both of which were relatively low compared to our results. The increase in dominance and density after a decade may be due to the positive effects of selection cutting and canopy opening that could promote growth and regeneration. A weak harvesting intensity can be in favor of tree dominance and density.

The normality hypothesis was rejected for the tree dominance and density of selection forests. Positive kurtosis can be affected by the single-tree selection policy, according to which trees were removed intensively from a dense stand with high dominance and were not removed in a sparse stand with low dominance. This policy may have resulted in the concentration on moderate dominance and density. Positive skewness may be due to recurrent selection cutting, which can cause the reduction of small trees in a stand. In fact, the mean juvenile density during 1986-1995 was large (717 individuals ha ${ }^{-1}$ ) (YAMAмото et al., 1996) relative to our results. This may be because selection forests partly suffered from unsuccessful regeneration caused by thick floor vegetation (i.e., Sasa spp.) (HosaKa $e t$ al., 2008) and injuries to residual trees by logging operations (Fukushi et al., 1997).

Two conifers of Sakhalin fir (A. sachalinensis) and Yezo spruce $(P$. jezoensis) with shade-tolerant broad-leaved tree species such as Japanese linden ( $T$. japonica), painted maple $(A$. mono) and Manchurian elm (U. laciniata) were growing in selection forests in central Hokkaido. Beech, a common tree species in central Europe, was not growing naturally in the UT Hokkaido Forest. Shade-intolerant broad-leaved tree species of Japanese oak (Q. crispula) and castor aralia (K. pictus) also had 
relatively high dominance. A large-scale natural disturbance (i.e., typhoon or fire) happened in the past probably gave an opportunity to introduce. Since these tree species had few juveniles in selection stands, their dominances may be decreasing in the future.

An inverse J-shaped diameter distribution that can be a desirable size structure as selection forests (O'HARA and GERSONDE, 2004) was maintained in tree density. Although the mean juvenile density seems to be decreasing, the number of succeeding trees may still be secured for the recovery of size structure after selection cutting. We observed a relatively large number of broad-leaved trees in small diameter classes. Smallscale canopy disturbances by selection cutting may affect positively the regeneration of broad-leaved tree species. The number of conifers exceeded in middle and large diameter classes. The growth rate of conifers is high enough to fill trees removed by selection cutting (IsHIBASHI, 1990).

Our results concerning geographic conditions were consistent with YамAMOTO et al. (1995), who previously examined elevation, inclination and slope aspect in the UT Hokkaido Forest. In this study, selection stands were mostly located between $300-600 \mathrm{~m}$ a.s.l., which was relatively low compared to Switzerland where selection forests are often distributed above $900 \mathrm{~m}$ a.s.l. (ZINGG et al., 1999). Mean annual temperature and precipitation are similar in both areas. In central Hokkaido, the climate on a high elevation may be too harsh to employ a selection system.

\section{CONCLUSIONS}

Natural selection forests in central Hokkaido can be characterized as contrasted with central Europe: 1) Tree dominance is relatively low, while tree density is considerably high in central Hokkaido. 2) Conifers belong to the same genera (Abies and Picea), while differences occur in major broad-leaved tree species (Fagus in Europe, Tilia in central Hokkaido). 3) An inverse $\mathrm{J}$-shaped diameter distribution is maintained in both regions. 4) Selection forests were distributed on a relatively low elevation in central Hokkaido.

This paper was intended to fairly represent the structure and geography of selection forests in central Hokkaido. A selection forest, however, have been changing its structure over time (O'HARA et al., 2007). Thus, future research should further examine the dynamics of selection stands in order to reveal the long-term effects of selection cutting in a natural forest.

\section{ACKNOWLEDGEMENTS}

We thank current and former technical staffs at the UT Hokkaido Forest for their continuous and great efforts collecting field data. We also acknowledge the reviewer and the editor for useful and helpful comments on an earlier draft of this manuscript. This study was partly supported by the Japan
Society for the Promotion of Science, Grant-in-Aid for Scientific Research (A), 19208015, 2007-2009.

\section{LITERATURE CITED}

AsaHI, M., (1963): Studies on the classification of forest soils in the Tokyo University Forest, Hokkaido. Bull. Tokyo Univ. For. 58: 1-132 (in Japanese with English summary)

BRown, J. D., (1997): Questions and answers about language testing statistics: Skewness and kurtosis. Shiken: JALT Testing \& Evaluation SIG Newsletter 1 (1): 20-23

Fukushi, K., Iwamoto, S., Kasahara, H., Sakaguchi, T., Ihara, S. and NitAMI, T., (1997): Development of timber harvesting system with a grapple skidder for selective cutting operation in natural forest management-forest disturbance and operational efficiency through skidding operation. Trans. Meet. Hokkaido Br. Jpn. For. Soc. 45: 146-148 (in Japanese)

GEOlogical SuRvey of JAPAN, (2003): Digital geological maps of Japan 1:200,000, South Hokkaido (G20-2)

HosaKa, T., OWarI, T. and GoTo, S., (2008): Relationships between the distribution and site conditions of Abies sachalinensis seedlings, saplings, and juveniles in selection cutting stands of natural forests in central Hokkaido, Japan. J. Jpn. For. Soc. 90: 357-363 (in Japanese with English summary)

ISHIBASHI, S., (1990): Studies on the structural dynamics of natural forest based on a simulation model. Bull. Tokyo Univ. For. 82: 11-101 (in Japanese with English summary)

IsHIBASHI, S., (1999): The selection cutting management plan of natural cool-temparate and boreal forests - The decision method of allowable cut volume and operation methods of each forest type. Jpn. J. For. Plann. 32: 7-19 (in Japanese with English summary)

NYLAND, R. D., (1998): Selection system in northern hardwoods. J. For. 96 (7): 18-21

O'HaRA, K. L. and Gersonde, R. F., (2004): Stocking control concepts in uneven-aged silviculture. Forestry 77: 131-143

O'Hara, K. L., Hasenauer, H. and Kindermann, G., (2007): Sustainability in multi-aged stands: an analysis of longterm plenter systems. Forestry 80: 163-181

OHGANE, E. (ed), (1981): The selection cutting systems as applied in Japan. Japan Forestry Invenstigation Committee, Tokyo, 370pp (in Japanese with English summary)

Owari, T., Inukai, H., Nakagawa, Y. and KaJI, M., (2009): Development of a GIS database in the stand-based forest management system. Trans. Jpn. For. Soc. Con. 120: 522 (in Japanese)

SchüTZ, J. P., (2001): Der Plenterwald und weitere Formen strukturierter und gemischter Wälder. Parey, Berlin, 207pp

Schütz, J. P., (2006): Modelling the demographic sustainability of pure beech plenter forests in Eastern Germany. Ann. For. Sci. 63: $93-100$

TAKAHASHI, N., (2001): The stand-based forest management system: its theory and practice (rev. ed.). Log Bee, Sapporo, 125pp (in Japanese) 
The ToKyo UnIVersity Forest In HoKKAIDO, (1997): The $11^{\text {th }}$ management and experiment plan of the Tokyo University Forest in Hokkaido (1996-2005). Misc. Inform. Tokyo Univ. For. 35: 1-124 (in Japanese)

The Tokyo UnIVERSity Forest IN HOKKAIDO, (2007): The $12^{\text {th }}$ management and experiment plan of the Tokyo University Forest in Hokkaido (2006-2015). Misc. Inform. Tokyo Univ. For. 46: 215-350 (in Japanese)

Yamamoto, H., Nitami, T. and KISandKI, H., (1995): Stand structure of mixed-species stands (I) Relation of species composition and topographic factors. J. Jpn. For. Soc. 77: 47-54 (in Japanese with English summary)

Yamamoto, H., Nitami, T. and KisanuKI, H., (1996): Analyzing stand structure of sub-boreal natural forests with attention to species properties. Res. Rep. Grant-in-Aid Sci. Res. (C) (No. 05806021), Ministry of Education, 94pp (in Japanese)

Yoshida, T., NoguchI, M., AKIBAyashi, Y., NOdA, M., Kado-
MATSU, M. and SASA, K., (2006): Twenty years of community dynamics in a mixed conifer - broad-leaved forest under a selection system in northern Japan. Can. J. For. Res. 36: 1363-1375

ZINGG, A., (1999):. English and German terminologies in forestry research on growth and yield: a few example. For. Snow Landsc. Res. 74: 179-187

ZingG, A., ErNI, V. and MoHr, C., (1999): Selection forests - a concept for sustainable use: 90 years of experience of growth and yield research selection forestry in Switzerland. In: Emmingham, W. H. (ed) Proc. of the IUFRO Interdisciplinary Uneven-aged Management Symposium, Oregon State Univ., Corvallis: $415-434$

(Received 23 September 2009)

(Accepted 22 December 2009) 